\title{
KSZTALCENIE NA KIERUNKACH STUDIÓW GEOINFORMACJA I GEOINFORMATYKA W WYBRANYCH UCZELNIACH W POLSCE
}

Zarys treści: Celem opracowania jest przedstawienie najważniejszych atutów ofert dydaktycznych polskich uczelni na kierunkach studiów w zakresie geoinformacji lub geoinformatyki. Szczególną uwagę zwrócono na podobieństwa oraz specyficzne wyróżniki na poszczególnych uczelniach. Studia w zakresie geoinformacji i geoinformatyki są prowadzone w Polsce na siedmiu uczelniach, w systemie bolońskim o profilu licencjackim lub inżynierskim. Liczba godzin zajęć dydaktycznych jest zróżnicowana i wynosi od 1890 do 2524 godzin na studiach pierwszego stopnia oraz od 772 do 1095 godzin na studiach drugiego stopnia. Studia na kierunkach geoinformacja i geoinformatyka są oceniane jako trudne, bowiem wymagają dobrego opanowania zagadnień, które dotychczas były (i nadal są) przedmiotem kilku różnych rodzajów studiów: przyrodniczych, geograficznych, geodezyjnych, matematycznych, statystycznych czy informatycznych. Cele studiów można uogólnić następująco: (1) wiedza niezbędna do zrozumienia funkcjonowania środowiska geograficznego, (2) umiejętności gromadzenia, przetwarzania, analizowania, interpretacji i wizualizacji danych geograficznych za pomocą (3) nowoczesnych technik i metod komputerowych lub/i (4) tworzenie narzędzi informatycznych wspierających te procesy. Realizowane kierunki studiów nie są jednakowe. Każda z uczelni nieco inaczej definiuje cele kształcenia swoich absolwentów: jednym zależy, aby posiadali oni wiedzę i umiejętności potrzebne do pomiaru przestrzeni i zjawisk, innym - aby zdobyte dane przestrzenne przetwarzali metodami informatycznymi, a jeszcze innym - aby stosowali geoinformację i geoinformatykę do poznawania mechanizmów funkcjonowania środowiska i społeczeństwa.

Słowa kluczowe: geoinformacja, geoinformatyka, GIS, kształcenie, studia wyższe.

\section{Wprowadzenie}

Współczesne przemiany w gospodarce światowej wyraźnie eksponują rosnące znaczenie informacji, która obok kapitału, surowców i zasobów pracy, staje się istotnym czynnikiem rozwoju. Kraje, które najwcześniej przestawią swoją gospodarkę 
na model oparty na wiedzy, mają szansę stać się liderami w wielu sektorach istotnych dla ich wewnętrznego funkcjonowania (administracji, nauce i szkolnictwie, służbie zdrowia, ochronie środowiska, telekomunikacji i wielu innych), a także na arenie międzynarodowej (choćby obronność, handel międzynarodowy i związane z nim przepływy towarów, ludzi, kapitału). Wiedza tworzona jest $\mathrm{z}$ informacji w oparciu o dane, a dane za pomocą odpowiednich metod i oprogramowania są pozyskiwane, przetwarzane i udostępniane docelowemu użytkownikowi. Specyficznym rodzajem danych są dane przestrzenne, które występują niemal w każdej sferze działalności człowieka, bowiem wszystko, co jest elementem naszego poznania i działalności ma odniesienie przestrzenne - jest związane z konkretnym „miejscem” w przestrzeni (Tobler 1970), a właściwie w czasoprzestrzeni, jeśli uwzględnimy także czynnik czasu (Langran 1993) albo w ogóle w wielowymiarowej przestrzeni, w której możemy definiować kolejne wymiary.

Początków systemów informacji geograficznej, w ich pierwotnym pojmowaniu (czyż starożytne mapy nie były systemem informacyjnym?), upatruje się w latach 60. ubiegłego wieku (Tomlinson 2008) czy w bardziej współczesnym rozumieniu w latach 80. ubiegłego wieku (Bartelme 1995). Pomimo znacznych i długotrwałych ograniczeń kontaktów ze światem zewnętrznym, znaczenie systemów informacji geograficznej (przestrzennej) dostrzeżono także w naszym kraju, czego skutkiem były liczne prace teoretyczne, a także aplikacyjne. Dyskusję terminologiczną nt. systemów informacji geograficznej, systemów informacji przestrzennej, informacji geograficznej, informacji geoprzestrzennej przedstawiają Z. Zwoliński (2010) oraz J. Gaździcki i in. (2018). Od razu też tematyka ta znalazła odzwierciedlenie w systemie kształcenia w szkolnictwie wyższym. Już w połowie lat 90. wiele kierunków studiów miało w swoich programach przedmioty nawiązujące wprost do geoinformacji (Olenderek i in. 1995; Adamczewski, Parzyński 2003; Zwoliński 2003, 2009, 2012; Olenderek, Olenderek 2004, 2009; Strzeliński 2004; Wężyk, Kozioł 2004; Widacki 2004; Białousz 2005, 2007; Kozak 2008). Choć trzeba wyraźnie stwierdzić, że takie nauki jak geografia, geodezja, kartografia, fotogrametria, teledetekcja, zaliczane dziś do „rdzenia” geoinformacji, były obecne w szkolnictwie wyższym już od wielu dekad.

Wraz z rozwojem kadr, nagromadzeniem doświadczenia, dostępnością sprzętu oraz coraz lepszego oprogramowania, przełamywaniem licznych barier finansowych, organizacyjnych i mentalnych, „wnikanie” przedmiotów geoinformacyjnych i geoinformatycznych do programów studiów stało się jeszcze bardziej widoczne, a proces ten zyskał także dodatkowe uzasadnienie w przyjętych koncepcjach rozwoju kraju i społeczeństwa informacyjnego (KBN 2000). Istotnym czynnikiem było przystąpienie Polski do Unii Europejskiej i przyjęcie Dyrektywy INSPIRE (Gaździcki 2005, 2006; Ney 2005). 
Do połowy drugiej dekady XXI wieku kształcenie w zakresie geoinformacji i/lub geoinformatyki było realizowane w ramach kierunków oraz specjalności (specjalizacji) lub studiów podyplomowych. Nauczanie systemów informacji geograficznej (GIS), a w tym geoinformacji i geoinformatyki, realizowane było od wielu lat, najczęściej w ramach kierunku geografia (na uniwersytetach) oraz kierunku geodezja i kartografia (na uczelniach technicznych). Programy zajęć były dopasowane do profili wydziałów i ich możliwości kadrowych, a metodykę kształcenia stale doskonalono (Będkowski 2004, 2006; Kozak, Szablowska-Midor 2009; Kozak i in. 2009, 2016; Kozak 2013; Będkowski i in. 2015; Białousz 2015; Białousz i in. 2015; Eckes 2015; Mościcka, Zwirowicz-Rutkowska 2015; Różycki i in. 2015; Stateczny 2016). Wymianie myśli i doświadczeń dydaktycznych dobrze służyły liczne konferencje naukowe, w tym m.in. „GIS w Edukacji” (Jażdżewska 2015ab; Jażdżewska i in. 2015) oraz nowe inicjatywy skierowane do studentów, takie jak Dzień GIS-u (Kunz 2011ab) oraz GIS Challenge (Hołub, Chabudziński 2017). Na wielu kierunkach nie rozwijano jednak nauk geoinformacyjnych i geoinformatycznych, a tylko próbowano nadążać za ich rozwojem, stąd „wdrażanie nowoczesnych technologii informatycznych najczęściej sprowadza się do wykorzystania dostępnego oprogramowania geoinformatycznego" (Stateczny 2009).

W ostatnich latach w kilku krajowych uczelniach podjęto kształcenie geoinformacyjne w ramach wyodrębnionych, dedykowanych kierunków studiów. Celem opracowania jest przedstawienie charakterystyki oferty dydaktycznej uczelni - kierunków studiów w zakresie geoinformacji/geoinformatyki, w tym szczególne wskazanie, w jakim zakresie są do siebie podobne i czym się szczególnie wyróżniają.

\section{Geoinformacja i geoinformatyka jako kierunek studiów}

Dyskusję nad utworzeniem nowych kierunków studiów geoinformacja i geoinformatyka rozpoczęła prezentacja Z. Zwolińskiego (2003) na Sympozjum Geoinformacji we Wrocławiu i Polanicy Zdroju, a następnie publikacje J. Gaździckiego $(2005,2006,2009)$ oraz obszerne opracowanie wykonane przez prof. Andrzeja Statecznego z Akademii Morskiej w Szczecinie, zawierające koncepcję kierunku oraz standardy kształcenia dla studiów pierwszego i drugiego stopnia (Stateczny 2009). W latach 2009-2010 odbyło się kilka spotkań przedstawicieli kierunków geografii, których celem było wypracowanie porównywalnego, choć oddającego specyfikę poszczególnych uczelni programu nauczania na studiach geoinformacyjnych. Konsultacje przeprowadzone w środowisku osób związanych z akademickim nauczaniem geoinformacji (Gaździcki i in. 2009), generalnie potwierdziły celowość uruchomienia tego rodzaju studiów, choć nie zabrakło głosów krytycznych, a nawet przeciwnych. Proponowane studia uznano za zgodne ze współczesnymi potrzebami i tendencjami kształcenia, które powinno mieć 
charakter uniwersalny (K. Eckes, uczestnik dyskusji w: Gaździcki i in. 2009). Studia powinny dać absolwentom szerokie szanse na znalezienie zatrudnienia, a także dobrze przygotować do zmieniającego się rynku pracy. Można się spodziewać, że głównym obszarem zastosowań geoinformatyki będzie działalność związana ze środowiskiem przyrodniczym (J. Michalak w: Gaździcki i in. 2009) i informatyką (A. Stepnowski i M. Moszyński w: Gaździcki i in. 2009). Również poważnym argumentem za utworzeniem kierunku geoinformatyka jest szybki rozwój rynku informacji w sektorze publicznym w Europie, bowiem informacja staje się poszukiwanym towarem (G. Szpor w: Gaździcki i in. 2009).

Wskazywano, że kierunek może być uruchomiony na wydziałach tych uczelni, które związane są z naukami o Ziemi (geografia, geologia, kartografia) lub naukami technicznymi (geodezja, kartografia, nawigacja i informatyka), a także rolniczymi, leśnymi lub wojskowymi i posiadają tradycje kształcenia w zakresie geoinformacji w ramach prowadzonych już przedmiotów, specjalizacji lub studiów podyplomowych. Studia początkowo mogłyby bazować na ich zasobie kadrowym, lokalowym, sprzętowym, oprogramowaniu i materiałach dydaktycznych (E. Bielecka w: Gaździcki i in. 2009).

Obawiano się jednak, że pozostawienie uczelniom dużej liczby godzin dydaktycznych do swobodnego kształtowania treści merytorycznych, podyktowane chęcią lepszego dopasowania oferty do możliwości danej uczelni, może doprowadzić do znacznego zróżnicowania realizowanej tematyki, co zaprzeczy idei przewodniej studiów geoinformatycznych (K. Eckes w: Gaździcki i in. 2009).

Zwracano uwagę, że proponowane studia będą wymagały poznania znacznego zakresu treści, nazwijmy je standardem geoinformatycznym, które z powodzeniem wypełniają czas przeznaczony na studia pierwszego stopnia. Czas na poznanie zastosowań przyjdzie na studiach stopnia drugiego, jednak nie do końca wiadomo, na bazie jakiej wiedzy? Stąd i pytanie, czy kształcenia w zakresie geoinformatyki nie realizować równolegle lub po studiach innych dziedzin wiedzy? (J. Kozak w: Gaździcki i in. 2009).

Kierunek geoinformatyka można też rozumieć (A. Stepnowski, M. Moszyński w: Gaździcki i in. 2009), jako kształcący informatyków w zakresie dodatkowej wiedzy z zakresu geodezji i kartografii. Przedmioty informatyczne byłyby zatem podstawowymi, natomiast wszystkie pozostałe powinny służyć zdobyciu wiedzy pozwalającej na przestrzenne umiejscowienie informacji.

Niezbędne jest jednakże zapewnienie odpowiedniego zaplecza naukowego - kierunek powinien być prowadzony przez jednostki, które będą w stanie rozwijać techniki i technologie geoinformatyczne. Nie da się bowiem stworzyć odpowiedniego zaplecza naukowego w uczelniach, które zajmują się geoinformatyką tylko na poziomie zastosowań (H. Olenderek i D. Korpetta w: Gaździcki i in. 2009). Pewną pośrednią drogą rozwiązania problemu jest propozycja utworzenia odrębnych profili kształcenia dla wydziałów geodezyjnych i informatycz- 
nych, gdzie byliby kształceni przyszli projektanci, administratorzy i użytkownicy systemów geoinformatycznych oraz dla innych wydziałów technicznych i przyrodniczych, których absolwenci mieliby kwalifikacje geoinformatyczne specjalizowane zgodnie z ich odmiennymi obszarami tematycznymi (W. Pachelski w: Gaździcki i in. 2009).

Wskazywano także, że geoinformacja niepotrzebnie wchodzi w zakres tradycyjnych i ukształtowanych już nauk geodezji i kartografii (T. Chrobak w: Gaździcki i in. 2009) oraz że trudno oczekiwać, iż zostanie uznana w naszym kraju za samodzielną dyscyplinę naukową, jak to jest za granicą (A. Iwaniak w: Gaździcki i in. 2009).

Decyzje o uruchomieniu kierunków studiów były podejmowane autonomicznie przez poszczególne uczelnie. Pierwsze jednolite 5-letnie studia magisterskie z zakresu geoinformacji uruchomiono w ramach kierunku geografia ze specjalnością geoinformacja (były one realizowane od I roku studiów) w roku akademickim 2002/2003 na Uniwersytecie im. Adama Mickiewicza w Poznaniu (Zwoliński 2012, tab. 1). Po wprowadzeniu w Polsce systemu bolońskiego, studia były kontynuowane na 3-letnich studiach licencjackich i 2-letnich studiach magisterskich od roku akademickiego 2007/2008. Zmiana Ustawy o szkolnictwie wyższym ${ }^{1}$ w $2011 \mathrm{r}$. umożliwiła uczelniom autonomiczne tworzenie kierunków studiów. Pierwsze kierunki studiów geoinformacja na polskich uczelniach zostały zaoferowane od roku akademickiego 2012/2013 na Uniwersytecie im. Adama Mickiewicza w Poznaniu oraz na Uniwersytecie Łódzkim. Na Uniwersytecie im. Adama Mickiewicza są to studia dwustopniowe o profilu inżynierskim (I stopnia 3,5-letnie oraz II stopnia 1,5-letnie), a na Uniwersytecie Łódzkim odpowiednio 3-letnie i 2-letnie.

Pierwsze studia w Polsce z zakresu geoinformacji, o nazwie geoinformacja środowiskowa, uruchomiono w roku akademickim 2013/2014 na Uniwersytecie Mikołaja Kopernika w Toruniu (tab. 1). Pomysł na tego typu kierunek studiów ewoluował przez kilkanaście lat (Kunz 2011ab, 2015). Wszystko przyspieszyło po pierwszych obchodach „Dnia GIS” w Toruniu w 2000 roku i powracało z narastającą siłą w kolejnych jego edycjach. Pojawiający się na tym święcie geoinformacji praktycy z czołowych firm sektora geotechnologii, zgodnie podkreślali potrzebę utworzenia nowego kierunku, który będzie dotyczył możliwości aplikacyjnego stosowania geoinformacji w zakresie badań środowiska. Przełomowe było również Rozporzadzenie w sprawie kształcenia technologii geoinformacyjnych wdrożone w Niemczech w 2010 roku. Skoro niemieccy pracodawcy widzieli taką potrzebę, to można było założyć, że i nasza gospodarka w najbliższym czasie będzie ją miała, mimo że nie myślano jeszcze wtedy o wprowadzeniu rozwiązań systemowych. Ten śmiały wówczas pomysł popierali także pracownicy krajowych firm branżowych, w których studenci seminarium kartografia i geoinformacja, realizowanego na kierunku geografia ówczesnego Instytutu Geografii UMK w Toruniu, odbywali obowiązkowe praktyki zawodowe.

${ }^{1}$ Dz.U., 2011, nr 84, poz. 455. 


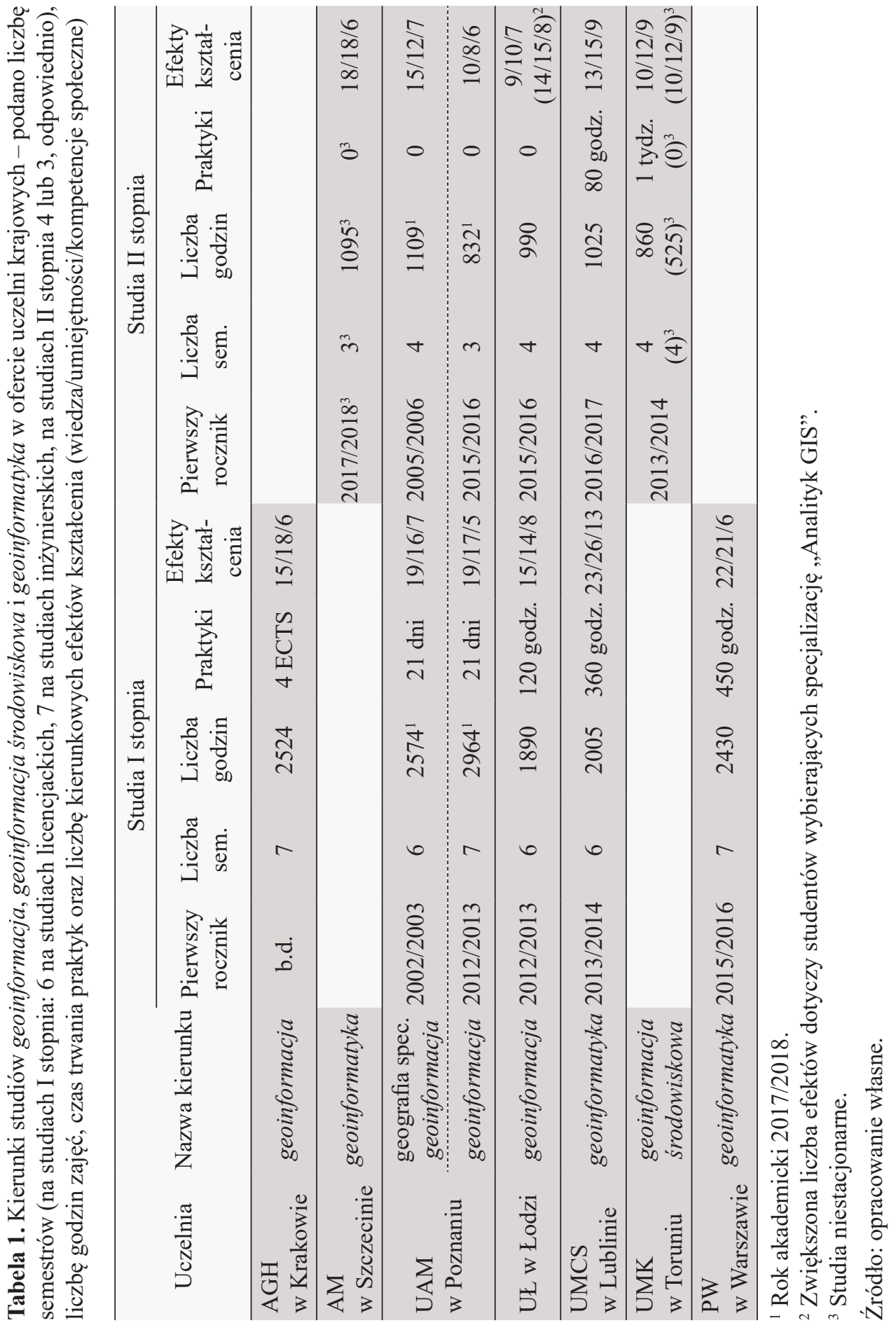


W roku akademickim 2013/2014 na Uniwersytecie Marii Curie-Skłodowskiej jako pierwszy w Polsce został uruchomiony kierunek - geoinformatyka (tab. 1), w ramach którego kształci się studentów na studiach pierwszego stopnia (profil praktyczny), a od 2016/2017 na studiach magisterskich (profil akademicki). Program studiów opracowano na podstawie doświadczeń edukacyjnych i praktycznych oraz zapotrzebowania dynamicznie rozwijającego się rynku pracy. Istotne znaczenie miała również wiedza i doświadczenia płynące ze współpracy krajowej i międzynarodowej. Oprócz podstaw teoretycznych, duży nacisk został położony na umiejętności praktyczne. Wśród prowadzących znajdują się doświadczeni nauczyciele akademiccy oraz eksperci-praktycy - przedstawiciele firm informatycznych i geoinformatycznych działających w Polsce i na świecie.

W roku akademickim 2015/2016 uruchomiono natomiast po raz pierwszy nauczanie na kierunku geoinformatyka na uczelni technicznej w Polsce. Zadanie to zrealizował Wydział Geodezji i Kartografii Politechniki Warszawskiej. Jest to podobnie jak w przypadku UMCS, kierunek o tzw. profilu praktycznym, co wymaga m.in. od studentów odbycia aż 12-tygodniowych praktyk produkcyjnych.

Obecnie studia geoinformacyjne znajdują się w ofercie dydaktycznej siedmiu uczelni (Zwoliński 2012; Jażdżewska 2016; Czekaj 2017; Geoinformatyka... 2017). W użyciu są trzy nazwy: geoinformacja (AGH - Akademia Górniczo-Hutnicza w Krakowie, UAM - Uniwersytet im. Adama Mickiewicza w Poznaniu, UŁ - Uniwersytet Łódzki), geoinformacja środowiskowa (UMK - Uniwersytet Mikołaja Kopernika w Toruniu), geoinformatyka (AM - Akademia Morska w Szczecinie, UMCS - Uniwersytet Marii Curie-Skłodowskiej w Lublinie, PW - Politechnika Warszawska). Nigdzie nie używa się na określenie kierunku nazwy geomatyka, mimo iż termin ten występuje za granicą i w Polsce, w tytułach podręczników i czasopism, nazwach konferencji naukowych, a także przedmiotów nauczanych na studiach różnych kierunków, w tym również na kierunkach geoinformacja i geoinformatyka. Prawdopodobną przyczyną jest chęć uniknięcia ewentualnej nieczytelności nazwy dla kandydatów na studia. Poza tym geomatyka bardziej kojarzy się ze studiami geodezyjnymi (technicznymi) aniżeli geograficznymi (uniwersyteckimi).

Kierunki geoinformacja i geoinformatyka różnią się między sobą nie tylko nazwą. Analiza programów studiów i efektów kształcenia ujawnia wiele elementów wspólnych, ale są też istotne różnice. Na obydwu kierunkach duży nacisk kładziony jest na kształtowanie wiedzy i praktycznych umiejętności z zakresu pozyskiwania, przetwarzania i wykorzystania informacji przestrzennej. Na geoinformatyce znaczną część (a nawet połowę) stanowią zajęcia poświęcone rozwijaniu kompetencji programistycznych i bazodanowych tak pożądanych w branży geoinformatycznej. Jest to zgodne z różnicami pojęciowymi między terminami geoinformacja a geoinformatyka. Warto przytoczyć w tym miejscu definicje zaczerpnięte z Internetowego Leksykonu Geomatycznego Polskiego Towarzystwa 
Informacji Przestrzennej. Geoinformacja to informacja uzyskiwana na drodze interpretacji danych geoprzestrzennych. Geoinformatyka to natomiast dziedzina zajmująca się stosowaniem informatyki w naukach o Ziemi oraz ich aplikacjach. Geoinformacja (nauka o geoinformacji, nauka geoinformacyjna) zajmuje się więc w większym stopniu analizą informacji przestrzennych, a geoinformatyka tworzeniem narzędzi i algorytmów wspomagających tego typu analizy i gromadzeniem danych. W pierwszym przypadku podstawowe teorie i metody pochodzą z dyscyplin geograficznych, a w drugiej z dyscyplin informatyka oraz geodezja i kartografia. Należy jednak wyraźnie podkreślić, że przedstawione rozróżnienia terminologiczne są dyskusyjne i wymagają uporządkowania.

Kierunki proponowane są zarówno jako stopnia pierwszego i drugiego, praktycznie wszystkie w trybie stacjonarnym (jedynym wyjątkiem jest oferta studiów niestacjonarnych na Uniwersytecie Mikołaja Kopernika w Toruniu). Studia stopnia pierwszego trwają 6 semestrów (licencjat) lub 7 (inżynierskie), natomiast drugiego stopnia odpowiednio 4 lub 3 semestry.

Obciążenie studentów, wyrażone liczbą godzin zajęć, jest dosyć zróżnicowane i wynosi 1890-2524 godzin na studiach pierwszego stopnia oraz 772-1095 godzin na studiach drugiego stopnia. Liczba godzin zajęć w poszczególnych semestrach układa się w uczelniach podobnie - na studiach pierwszego stopnia jest równomiernie rozłożona, $\mathrm{z}$ wyraźnym spadkiem w końcowych semestrach (ryc. 1), zaś na studiach magisterskich systematycznie spada po pierwszym dosyć intensywnym roku nauki (ryc. 2). Studenci, głównie pierwszego stopnia, mają także obowiązek odbywania praktyk.

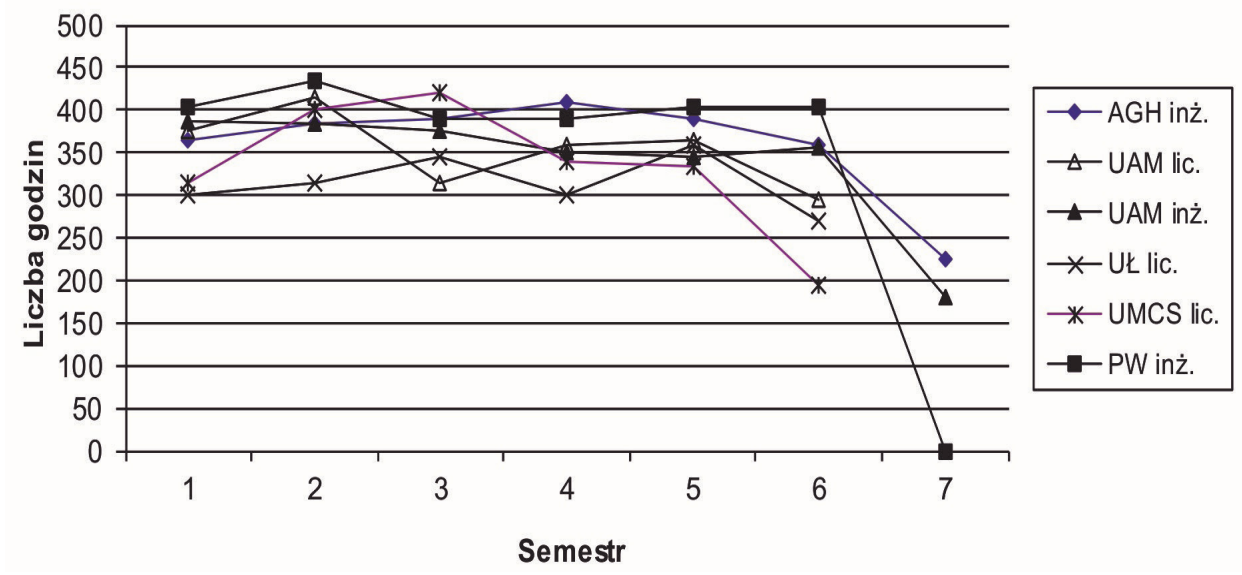

Ryc. 1. Liczba godzin zajęć dydaktycznych w poszczególnych semestrach (studia pierwszego stopnia) - (w przypadku PW inż., semestr 7 to 0 godz.) Źródło: opracowanie własne. 


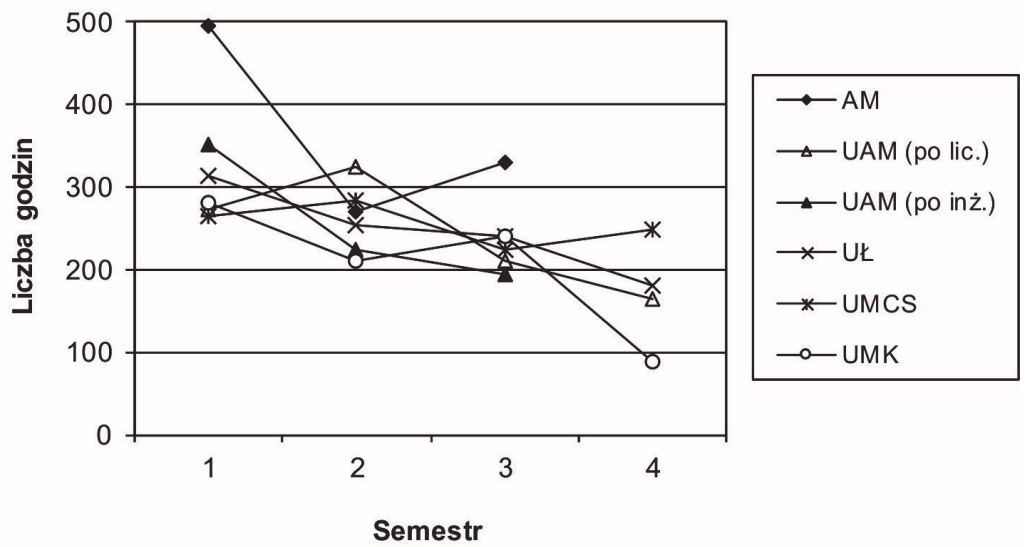

Ryc. 2. Liczba godzin zajęć dydaktycznych w poszczególnych semestrach (studia drugiego stopnia)

Źródło: opracowanie własne.

\section{Cele ksztalcenia na kierunkach geoinformacja i geoinformatyka}

Cele studiów sformułowane w opisach kierunków są w zasadzie bardzo podobne. Zdobyta wiedza ma umożliwić absolwentom wykonywanie prac z zakresu pozyskiwania, przetwarzania i udostępniania informacji o terenie w branży informatycznej, w instytucjach i przedsiębiorstwach zajmujących się realizacją zadań z zakresu geoinformacji, geodezji i kartografii, informatyki oraz systemów informacji przestrzennej. Szczegółowym zapisem celów są tzw. kierunkowe efekty kształcenia. Ambicją uczelni jest, aby absolwenci studiów pierwszego stopnia osiągnęli po około 15-20 efektów w zakresie wiedzy i umiejętności oraz 6-8 z kompetencji społecznych. Dla studiów drugiego stopnia sformułowano wyraźnie mniej efektów, mają one jednakże odmienny charakter, gdyż odwołują się do bardziej ogólnego, całościowego postrzegania geoinformacji i geoinformatyki, kierunków ich rozwoju i zagadnień o charakterze naukowym.

W świetle analizy kierunkowych efektów kształcenia można stwierdzić, że studia na kierunkach geoinformacja i geoinformatyka są dosyć trudne, bowiem wymagają dobrego opanowania zagadnień, które dotychczas były (i nadal są) przedmiotem kilku różnych rodzajów studiów: przyrodniczych, geograficznych, geodezyjnych, matematycznych, statystycznych czy informatycznych. Zapisane cele można uogólnić do stwierdzenia, że absolwent kierunku geoinformatyka powinien posiadać: (1) wiedzę niezbędną do zrozumienia funkcjonowania środowiska geograficznego, a także zdobyć (2) umiejętności gromadzenia, przetwarzania, wizualizacji, analizowania i interpretacji danych geograficznych za pomocą (3) nowoczesnych technik i metod komputerowych (z opisu kierunku geoinformacja na Uniwersytecie 
im. Adama Mickiewicza, punkty pochodzą od autorów artykułu). Dla zilustrowania posłużymy się nieznacznie zmienioną listą efektów kształcenia, przyjętych dla studiów pierwszego stopnia (inżynierskich) na Akademii Górniczo-Hutniczej w Krakowie, która jest bardzo zbliżona do efektów sformułowanych również dla kierunku geoinformatyka na Politechnice Warszawskiej.

Absolwent geoinformatyki na AGH i PW powinien posiadać wiedzę z zakresu:

- matematyki, statystyki, fizyki;

- informatyki, w tym: architektury systemów i sieci komputerowych, algorytmów, baz danych, oprogramowania do pomiarów, obliczeń geodezyjnych, tworzenia map cyfrowych, projektowania aplikacji geoinformacyjnych, metod zarządzania projektami geoinformacyjnymi;

- metod i systemów pozyskiwania danych geodezyjnych, fotogrametrycznych i teledetekcyjnych;

- budowy i zasad działania przyrządów pomiarowych oraz ich dokładności i dokładności pomiarów;

- kartograficznego modelowania danych 2D, 3D oraz tworzenia map cyfrowych;

- uregulowań prawnych dotyczących pozyskiwania, przetwarzania i udostępniania danych przestrzennych;

- zarządzania, form indywidualnej przedsiębiorczości;

- zarządzania jakością, ochrony własności intelektualnej i prawa autorskiego. Niezbędne umiejętności absolwenta dotyczą:

- pozyskiwania informacji z literatury, baz danych i innych, w tym obcojęzycznych;

- pracy indywidualnej i zespołowej (szacowanie czasu, harmonogram, przejmowanie różnych ról);

- opracowywania dokumentacji projektowej i komentowania/przedstawiania wyników;

- posługiwania się językiem obcym (angielskim);

- samokształcenia;

- analizy podstawowych zagadnień fizycznych i technicznych z wykorzystaniem aparatu matematycznego;

- wykonywania pomiarów i obliczeń geodezyjnych, fotogrametrycznych oraz kartograficznych;

- programowania $\mathrm{w}$ różnych środowiskach programistycznych;

- projektowania, tworzenia i zarządzania bazami danych geoprzestrzennych;

- projektowania i przeprowadzenia analiz przestrzennych w środowisku SIP/ GIS.

Do kompetencji społecznych zaliczono:

- rozumienie potrzeby ciągłego dokształcania się;

- świadomość technicznych, środowiskowych, prawnych i społecznych skutków własnej działalności; 
- odpowiedzialność za podejmowane decyzje;

- przestrzeganie zasad etyki zawodowej, poszanowanie różnorodności poglądów i kultur;

- przestrzeganie zasad pracy zespołowej, w tym ponoszenie odpowiedzialności za jej efekty;

- myślenie i działanie w sposób przedsiębiorczy;

- świadomość roli społecznej absolwenta uczelni wyższej, w tym potrzeby popularyzacji wiedzy.

Podobne do wymienionych powyżej efekty kształcenia przyjęto we wszystkich uczelniach prowadzących studia z zakresu geoinformacji (geoinformatyki). Efekty studiów drugiego stopnia są podobne, jednak wyróżnia je bardziej „,naukowy” charakter.

Szeroki zakres kształcenia znajduje odbicie w nazwach wykładanych przedmiotów. Nie sposób przytoczyć tu całych programów studiów dla wszystkich kierunków, jednak na pewno warto zauważyć pewne ich specyficzne elementy i cechy. I tak, w uczelniach posiadających tradycje w kształceniu w zakresie geodezyjnym i kartograficznym (AGH, PW, AM) jest wiele przedmiotów typowych dla kształcenia geodetów. Studenci zdobywają solidną wiedzę i umiejętności dotyczące głównie pozyskiwania danych i ich odpowiedniego lokowania w przestrzeni, a także budowy i funkcji urządzeń do tego celu służących oraz tworzenia odpowiednich baz danych. Znacznie mniej przewidziano zajęć związanych $\mathrm{z}$ tematycznym przetwarzaniem informacji środowiskowych, a więc takich, w którym istotnym jest zrozumienie złożoności funkcjonowania systemów społecznych, gospodarczych i przyrodniczych. Odwrotnie jest na uczelniach posiadających wydziały zajmujące się naukami geograficznymi (UAM, UŁ, UMK), w których akcent nauczania położony jest właśnie na metody przetwarzania danych przestrzennych, co jest podkreślane w licznych przedmiotach z nauk o Ziemi i środowisku. Można zaryzykować stwierdzenie, że gdzieś w środku między tymi dwoma biegunami znajduje się oferta UMCS, gdzie geoinformatyka jest kierunkiem międzyobszarowym. Wyraża to tożsame nauczanie z zakresu geografii, informatyki (programowania i zarządzania bazami danych) oraz systemów informacji przestrzennej, przy czym szczególny nacisk położony jest na praktyczne aspekty zastosowań zdobywanej wiedzy. Jedne uczelnie kształcą specjalistów bardziej w kierunku pozyskiwania danych (ich wytwarzania), inne natomiast zwracają uwagę głównie na to, skąd dane (najczęściej są to gotowe produkty) wziąć i jakimi metodami je przetworzyć, aby uzyskać wyniki odpowiednich analiz dotyczących zjawisk społecznych lub przyrodniczych. Przykładowo, na jednej uczelni absolwent nauczy się jak wykonuje się zdjęcia lotnicze i jak można wytworzyć z nich odpowiednimi technologiami i z odpowiednią dokładnością ortofotomapę, a na innej, jak za jej pomocą wyodrębnić obszary funkcjonalne miasta, albo np. ocenić stan zdrowotny lasów, stosując odpowiednie metody wypracowane w obszarze nauk geograficznych lub leśnych. 


\section{Cechy charakterystyczne poszczególnych kierunków studiów}

Poniżej przedstawiono specyficzne cechy kształcenia na kierunkach geoinformacja i geoinformatyka w wybranych uczelniach:

- Kierunkowe efekty kształcenia AGH w Krakowie uwzględniają przedmioty głównie dla geodetów, choć w siatce godzin są i te (około 1/5), które dają wiedzę niezbędną do zrozumienia funkcjonowania środowiska geograficznego.

- Akademia Morska w Szczecinie nie narzuciła „morskiego” charakteru na swoją geoinformatykę. W programie studiów jest tylko jeden specyficzny przedmiot - „Nowoczesne morskie technologie pomiarowe”.

- UAM w Poznaniu prowadzi kierunek geoinformacja pierwszego i drugiego stopnia oraz równolegle specjalność geoinformacja na kierunku geografia (na studiach I i II stopnia). Kierunek geoinformacja drugiego stopnia ma dwie specjalności: geoinformatyka oraz infrastruktura krytyczna, realizowana w ramach projektu PO WER. Infrastruktury krytycznej i związanych z nią przedmiotów nie ma w żadnej innej uczelni, a są to (podano liczbę wykładów/ ćwiczeń): Podstawy prawne ochrony IK w Polsce (10/-), Organy i podmioty zapewniające ochronę IK (10/-), Europejska infrastruktura krytyczna (10/-), Systemy infrastruktury krytycznej (10/-), Ochrona IK (10/-), Systemy monitoringowe w mieście (10/-), Drony w sytuacjach kryzysowych (15/15), Miejskie systemy geoinformacyjne (10/-), Wojskowe s.g. (10/-), Modelowanie geozagrożeń (15/30), Bezpieczeństwo sieci teleinformatycznych (15/-), Zarządzanie logistyczne w sytuacjach kryzysowych (15/20), Prognozowanie zagrożeń dla IK (10/10), Ochrona informacji wrażliwych (10/-), Terroryzm jako szczególne zagrożenie dla IK (10/-), Zarządzanie stresem i kontrola emocji (-/15), Zarządzanie i ochrona zasobów żywnościowych (15/15).

- Wydział Nauk Geograficznych Uniwersytetu Lódzkiego prowadzi geoinformację wspólnie z Wydziałem Matematyki i Informatyki, stąd silny akcent na programowanie oraz możliwość zdobycia tytułu „Analityk GIS” (po osiągnięciu przez studenta dodatkowych efektów kształcenia). Kształtuje się wiedzę i umiejętności dotyczące ModelBuilder'a, programowanie w językach Java, podstawy klasyfikacji obiektowej, znajomość otwartego oprogramowania oraz rozumienie złożonych zjawisk przestrzennych i znajomość zaawansowanych metod ich analizy (zob. także Jażdżewska 2016).

- Specyfiką kierunku geoinformatyka na UMCS w Lublinie jest zrównoważona obecność w programie studiów przedmiotów zarówno dających wiedzę niezbędną do zrozumienia funkcjonowania środowiska geograficznego, jak i zaawansowanych metod pozyskiwania danych i analiz przestrzennych. Stanowią one około $50 \%$ całości, które dopełnia rozbudowany blok przedmiotów matematyczno-informatycznych. Przykłady przedmiotów z programu studiów pierwszego stopnia (wykłady/ćwiczenia): Podstawy GIS(15/45), Przestrzeń 
geograficzna i jej funkcjonowanie (20/30), GIS w badaniach środowiska (-/15), Podstawy ekofizjografii (15/30), Mechanika nieba (15/30), Geometria analityczna (15/15), Podstawy programowania i algorytmizacji (30/40), Podstawy programowania $\mathrm{C} / \mathrm{C}++(15 / 30)$, Środowisko programisty (-/30), Bazy danych i zarządzanie informacją (15/30), Rachunek prawdopodobieństwa i statystyka (30/30), Analiza przestrzenna (15/30), Podstawy programowania aplikacji GIS (10/30), Podstawy geoprzetwarzania (-/30), Geowizualizacja z elementami redakcji kartograficznej (15/30), Podstawy teledetekcji (15/30).

- Geoinformacja środowiskowa na UMK w Toruniu, prowadzona jako studia drugiego stopnia, to pionierskie w skali kraju interdyscyplinarne połączenie wiedzy geograficznej, geodezyjno-kartograficznej oraz informatycznej. Jej absolwenci (a kierunek kończy za pół roku właśnie piąty rocznik) są przygotowani do kompleksowej analizy stanu i zasobów środowiska geograficznego oraz zarządzania informacją o jego komponentach nowoczesnymi narzędziami informatycznymi i geomatycznymi. Zarówno absolwenci kierunku, jak i interesariusze zewnętrzni (pracodawcy oraz firmy przyjmujący na praktyki zawodowe) bardzo pozytywnie oceniają studia i ich program, przygotowanie zawodowe studentów, w tym umiejętności obsługi oprogramowania geoinformacyjnego oraz myślenie analityczne, a także upraktycznienie prac dyplomowych, które wielokrotnie powstają na wyraźne zapotrzebowanie i współpracę z otoczeniem zewnętrznym. Według pracowników UMK, wyróżnikami są m.in.: uczestnictwo studentów kierunku w pracach naukowych (np. w opracowaniu Internetowego Atlasu Województwa Kujawsko-Pomorskiego), nowoczesne laboratoria komputerowe, w tym pracownia mobilna, oferta stypendiów wyjazdowych w ramach programu Erasmus + do kilkudziesięciu europejskich uczelni, wykłady eksperckie, praktyczne poznanie (zgodnie z programem studiów) trzech typów oprogramowań z grupy GIS, a także możliwość uczestniczenia w projektach PO WER (Program Operacyjny Wiedza, Edukacja, Rozwój), z których w minionych trzech latach finansowane były dodatkowe, autoryzowane szkolenia geoinformatyczne, w tym szkolenia państwowe na operatorów bezzałogowych statków powietrznych w zakresie VLOS (ang. Visual Line of Sight - loty w zasięgu wzroku), szkolenia z zakresu skaningu laserowego i szkolenia oferowane przez firmę Esri, a także (dla absolwentów do 2022 roku) wysokojakościowe, kilkumiesięczne staże zawodowe w całym kraju (zob. także Kunz 2015 i 2017).

- Kierunek geoinformatyka na Politechnice Warszawskiej to pierwszy kierunek o tej nazwie na uczelni technicznej w Polsce. Jest to kierunek o tzw. profilu praktycznym, co wymaga m.in. od studentów odbycia aż 12-tygodniowych praktyk produkcyjnych. Specyfiką kierunku jest przygotowanie absolwentów zdolnych do tworzenia narzędzi wykorzystywanych w szeroko rozumianej dziedzinie geoinformacji. Zgodnie z oficjalnym opisem sylwetki absolwenta, 
powinni być przygotowani do tworzenia zarówno takich popularnych rozwiązań, jak portale typu Google Maps, nawigacja samochodowa, elektroniczne przewodniki turystyczne, mapy świata $\mathrm{w}$ grach komputerowych, jak i produktów do użytku profesjonalnego, np. systemów przetwarzania danych teledetekcyjnych pozyskiwanych z pułapu satelitarnego, systemów automatyzacji pomiarów wykonywanych z dronów, modeli 3D budynków, systemów optymalizacji ruchu czy systemów monitoringu przyrody. Ze względu na konieczność przetwarzania ogromnych zbiorów danych, studenci zapoznawani są z zagadnieniami spatial big data i spatial data mining, nowoczesnymi technologiami pozyskiwania danych (w szczególności bezinwazyjnymi, np. skaning laserowy, fotogrametria i teledetekcja) oraz systemami analiz danych przestrzennych (GIS). Na kierunku geoinformatyka realizowany jest rozbudowany program z zakresu informatyki (przede wszystkim programowania i baz danych - ok. 500 godz., nie licząc innych zagadnień informatycznych), ale opierający się na konkretnych przykładach z zakresu dyscypliny geodezja i kartografia oraz szeroko rozumianych nauk geoinformacyjnych (GIScience). Studenci obowiązkowo poznają m.in. język C++ oraz JAVA lub Python, a także system Oracle Spatial. Wspólny z kierunkiem geodezja i kartografia blok przedmiotów geodezyjno-kartograficznych pozwala na wspólną naukę przez studentów dwóch pokrewnych kierunków - takie podejście ma na celu możliwie głęboką integrację studentów geoinformatyki ze studentami geodezji i kartografii, w celu wspólnego definiowania potrzeb rynku. Jako unikalne w stosunku do oferty innych uczelni, można też uznać takie przedmioty, jak: Inteligentne miasta (smart cities), Modelowanie informacji o budynkach (BIM), Inteligentne systemy transportowe (ITS) oraz nauczanie metodą Design Thinking. Studenci zdobywają też profesjonalne certyfikaty z zakresu GIS i CAD w ramach realizacji projektu PO WER.

Zapisane w efektach kształcenia cele podzielone są na trzy grupy: wiedza, umiejętności i kompetencje społeczne. W uczelniach w procesie dydaktycznym zwraca się na nie uwagę zwykle w wymienionej wyżej kolejności, najmniej wagi przywiązując do tzw. kompetencji miękkich. Tymczasem są one równie istotne, o czym mówią nauczyciele zajmujący się dydaktyką GIS (Mościcka, Zwirowicz-Rutkowska 2015). Specjaliści - pracodawcy z branży geoinformatycznej - zauważają, że we współczesnym świecie następuje odwrócenie kolejności. Najważniejszymi dla sukcesu absolwentów stają się kompetencje miękkie (umiejętność pracy w zespole, przyjmowanie w nim różnych ról, sztuka autoprezentacji i in.), następnie umiejętności (potrafię to zrobić), a na końcu wiedza (wiem dlaczego tak jest). Tych ostatnich wymaga się w większym zakresie od kadry kierowniczej²

${ }^{2}$ Na podstawie wyników badań własnych dr. hab. inż. Piotra Wężyka (występującego w roli pracodawcy), przedstawionych podczas II Konferencji „GIS w Edukacji”, Wydział Nauk Geograficznych, Uniwersytet Łódzki, Łódź 14-15 czerwca 2018 roku. 
W nauczaniu w zbyt małym stopniu korzystamy z metod nauczania na odległość (e-learningu), chociaż większość dydaktyków docenia korzyści płynące $\mathrm{z}$ tego rozwiązania. Wydaje się, że w najbliższym czasie wzorem amerykańskich uczelni, e-kursy w zakresie wybranych zagadnień dotyczących geoinformacji będą coraz liczniej pojawiały się w programach kształcenia, jako wspomagająca metoda nauczania.

\section{Wnioski}

Powołana przez prof. Jerzego Gaździckiego grupa ekspertów (Gaździcki i in. 2009), rozumiana jako całość, trafnie zidentyfikowała różnorodne problemy, jakie wiążą się z uruchomieniem kierunków studiów geoinformacja i geoinformatyka. Część z nich została zaakcentowana we wstępie do niniejszego artykułu. Realizowane kierunki studiów nie są jednakowe. Każda z uczelni nieco inaczej buduje profil absolwenta: jedne chcą, aby posiadł głównie wiedzę i umiejętności potrzebne do pomiaru przestrzeni i zjawisk, inne - aby zdobyte dane dobrze przetwarzał metodami informatycznymi, a jeszcze inne, aby stosował geoinformatykę do poznawania mechanizmów funkcjonowania środowiska i społeczeństwa.

Zarysowany podział podobny jest do tego, w którym uczestnika społeczności geoinformacyjnej będziemy widzieli jako twórcę, użytkownika lub tylko obserwatora systemów geoinformacyjnych. Zatem, jak pisali J. Kozak i A. Szablowska-Midor (2009), nie ma jednej formuły studiów z zakresu geoinformacji i geoinformatyki, są raczej różne warianty kształcenia, w zależności od pożądanego profilu absolwenta oraz oczekiwanego poziomu jego kompetencji. Kandydat na studia ma możliwość wyboru profilu odpowiadających mu studiów, uczelnia możliwość kształcenia w zakresie, do którego jest najlepiej przygotowana, a społeczeństwo i gospodarka otrzymuje różnych absolwentów, przygotowanych do pełnienia różnorodnych ról w łańcuchu przetwarzania informacji przestrzennych.

\section{Podziękowania}

Autorzy dziękują za udostępnienie danych dotyczących programów studiów, kierunkowych efektów kształcenia oraz opisów kierunków. W artykule wykorzystano także informacje zawarte na stronach internetowych uczelni.

\section{Literatura}

Adamczewski Z., Parzyński Z., 2003, Problem przekazu wiedzy o systemach informacji przestrzennej w ksztatceniu geodetów, „Przegląd Geodezyjny”, 12: 8-10.

Bartelme N., 1995, Geoinformatik - Modelle, Strukturen, Funktionen, Springer Verlag, Berlin/Heidelberg.

Będkowski K., 2004, Studium Podyplomowe „Zastosowanie Systemów Informacji Przestrzennej w Leśnictwie i Ochronie Przyrody”, „Roczniki Geomatyki”, II(3): 37-42. 
Będkowski K., 2006, Studium Podyplomowe „Zastosowanie Systemów Informacji Przestrzennej w Leśnictwie i Ochronie Przyrody” z perspektywy czterech lat, „Roczniki Geomatyki", IV(4): 169-176.

Będkowski K., Brach M., Hawryło P., Kwaśny Ł., Olenderek T., Strzeliński P., Szostak M., Szymański P., Tracz W., Wężyk P., 2015, Geomatics Education of Foresters at Agriculture Universities, [w:] Jażdżewska I. (red.), GIS in Higher Education in Poland. Curriculums, Issues, Discussion, Wydawnictwo Uniwersytetu Łódzkiego, Łódź: 36-59.

Białousz S., 2005, Stan obecny i koncepcja kształcenia $w$ zakresie Systemów Informacji Przestrzennej, Politechnika Warszawska, Warszawa.

Białousz S., 2007, Kształcenie w zakresie systemów informacji przestrzennej dla administracji publicznej. Potrzeby, stan i rozwój, „Roczniki Geomatyki”, V, 6: 9-22.

Białousz S., 2015, Personalizacja kształcenia użytkowników informacji przestrzennej, „Roczniki Geomatyki”, XIII, 3(69): 193-199.

Białousz S., Chmiel J., Lady-Drużycka K., Fijałkowska A., 2015, Ewolucja programu nauczania na studiach podyplomowych SIP w Politechnice Warszawskiej, ,Roczniki Geomatyki", XIII, 2(68): 83-98.

Czekaj D., 2017, My, geoinformatycy, „Geodeta”, 7(266): 26-30.

Eckes K., 2015, Nauczanie GIS z wykorzystaniem naturalnych procesów poznawczych, „Roczniki Geomatyki”, XIV, 2(72): 183-191.

Gaździcki J., 2005, Implikacje Dyrektywy INSPIRE, „,Roczniki Geomatyki”, III, 3: 19-25.

Gaździcki J., 2006, Zakres tematyczny dziedziny geoinformacji jako nauki i technologii, „Roczniki Geomatyki”, IV, 2: 15-27.

Gaździcki J., 2009, Studia wyższe $w$ dziedzinie geoinformacji: aspekty modernizacji w Polsce, „Roczniki Geomatyki”, VII, 3(33): 7-12.

Gaździcki J., Bielecka E., Chrobak T., Eckes K., Iwaniak A., Kozak J., Michalak J., Olenderek H., Korpetta D., Pachelski W., Stepnowski A., Moszyński M., Szpor G., 2009, Opinie na temat koncepcji utworzenia kierunku studiów $w$ dziedzinie geoinformacji, „Roczniki Geomatyki”, VII, 3(33): 135-158.

Gaździcki J., Gotlib D., Jażdżewska I., Zwoliński Z., 2018, Aktualne aspekty edukacji geoprzestrzennej w Polsce, ,Roczniki Geomatyki”, XVI, 3(82): 235-240.

Geoinformatyka również w Szczecinie, „Geodeta”, 8(267): 43.

Hołub B., Chabudziński Ł., 2017, I Akademickie Mistrzostwa Geoinformatyczne - GIS Challenge 2017 w Lublinie, „Polski Przegląd Kartograficzny”, 49(1): 144-145.

Internetowy Leksykon Geomatyczny, Polskie Towarzystwo Informacji Przestrzennej, https://www.ptip.info/leksykon.

Jażdżewska I., 2015a, GIS in Polish Higher Education - a Discussion, [w:] Jażdżewska I. (red.), GIS in Higher Education in Poland. Curriculums, Issues, Discussion, Wydawnictwo Uniwersytetu Łódzkiego, Łódź: 90-110.

Jażdżewska I. (red.), 2015b, GIS in Higher Education in Poland. Curriculums, Issues, Discussion, Wydawnictwo Uniwersytetu Łódzkiego, Łódź.

Jażdżewska I., 2016, Oferta edukacyjna geoinformacji na Wydziale Nauk Geograficznych Uniwersytetu Łódzkiego 2015/2016, „Roczniki Geomatyki”, XIV, 3(73): 351-362.

Jażdżewska I., Werner P., Zwoliński Z., 2015, Current State and Future Perspectives of University Education of GIS and Geoinformation in Poland, [w:] Jażdżewska I. (red.), 
GIS in Higher Education in Poland. Curriculums, Issues, Discussion, Wydawnictwo Uniwersytetu Łódzkiego, Łódź: 5-23.

KBN, 2000, Cele ikierunki rozwoju społeczeństwa informacyjnego w Polsce, KomitetBadań Naukowych, Ministerstwo Łączności, Warszawa, 28 listopada 2000 r. (http://kbn.icm. edu.pl/cele/cele.html).

Kozak J., 2008, Nauczanie teorii i technologii informacji geograficznej na studiach geograficznych na Uniwersytecie Jagiellońskim: uwarunkowania i perspektywy, ,Roczniki Geomatyki", VI, 5: 39-48.

Kozak J., 2013, Jerzy Bański: Jaka geografia? Uwarunkowania i spojrzenie w przyszłość: głos $w$ dyskusji, „Przegląd Geograficzny”, 85(3): 455-461.

Kozak J., Balon J., Gwosdz K., Piotrowicz K., Szablowska-Midor A., Trzepocz A., 2016, Nowe studia z gospodarki przestrzennej w Instytucie Geografii i Gospodarki Przestrzennej Uniwersytetu Jagiellońskiego, ,Roczniki Geomatyki”, XIV, 3(73): 375-386.

Kozak J., Szablowska-Midor A., 2009, Pożądane kompetencje absolwentów studiów geoinformatycznych: doświadczenia Instytutu Geografii i Gospodarki Przestrzennej Uniwersytetu Jagiellońskiego, „Roczniki Geomatyki”, VII, 6(36): 73-80.

Kozak J., Werner P., Zwoliński Z., 2009, Kształcenie w zakresie geoinformatyki na kierunku geografia, „Roczniki Geomatyki”, 3(33): 57-73.

Kunz M., 2011a, The International GIS Day-Analysis of Celebrations in Poland and its Importance to Geographic Education, „Prace i Studia Geograficzne”, 48: 197-209.

Kunz M., 2011b, Światowy dzień GIS - analiza obchodów w Polsce i jego znaczenie w edukacji geograficznej, „Roczniki Geomatyki”, IX, 4(48): 93-103.

Kunz M., 2015, Geoinformacja środowiskowa w Toruniu - projekt edukacyjny zakończony sukcesem, „ArcanaGIS”, Magazyn dla użytkowników oprogramowania ESRI, Wiosna 2015, 15: 16-17.

Kunz M., 2017, Rozwój geokompetencji studentów Wydziału Nauk o Ziemi UMK w Toruniu, Edukacja, Esri Polska, Warszawa: 11-12.

Langran G., 1993, Time in Geographical Information Systems, Taylor and Francis, London.

Mościcka A., Zwirowicz-Rutkowska A., 2015, Rozwijanie kompetencji miękkich w zakresie projektowania systemów geoinformacyjnych, ,Roczniki Geomatyki”, XIII, 3(69): 255-264.

Ney B., 2005, Geoinformacja w spoteczeństwie informacyjnym, „Roczniki Geomatyki”, III, 3: 11-18.

Olenderek H., Korpetta D., Będkowski K., Czajko M., Nowicki A., 1995, ARC/INFO in GIS Education at The Faculty of Forestry, $10^{\text {th }}$ European ARC/INFO User Conference, Prague, 2-4 October 1995: VI-5-VI-9.

Olenderek H., Olenderek T., 2004, Kształcenie w zakresie geomatyki na wydziałach leśnych, ,Roczniki Geomatyki”, II, 3: 27-30.

Olenderek H., Olenderek T., 2009, Problematyka ksztatcenia w zakresie geoinformacji na kierunku leśnictwo, „Roczniki Geomatyki”, VII, 3(33): 37-43.

Różycki S., Fijałkowska A., Marczak S., Radło-Kulisiewicz M., 2015, Nowa koncepcja nauczania podstaw systemów informacji przestrzennej na Wydziale Geodezji i Kartografii PW, „Roczniki Geomatyki”, XIII, 3(69): 265-276. 
Stateczny A., 2009, Koncepcja kierunku studiów w dziedzinie geoinformacji, „Roczniki Geomatyki”, VII, 3(33): 125-134.

Stateczny A., 2016, Ksztatcenie w zakresie geoinformacji w Akademii Morskiej w Szczecinie, ,Roczniki Geomatyki”, XIV, 2(72): 213-219.

Strzeliński P., 2004, Działalność naukowa i dydaktyczna w zakresie leśnej geomatyki na Wydziale Leśnym Akademii Rolniczej w Poznaniu, „,Roczniki Geomatyki”, II, 3: 58-64.

Tobler W., 1970, A Computer movie Simulating Urban Growth in the Detroit Region, „Economic Geography”, 46: 234-240.

Tomlinson R., 2008, Rozważania o GIS. Planowanie Systemów Informacji dla Menadżerów, ESRI Polska, Warszawa.

Wężyk P., Kozioł K., 2004, Edukacja geoinformatyczna studentów Wydziału Leśnego Akademii Rolniczej w Krakowie, „Roczniki Geomatyki”, II, 3: 50-57.

Widacki W., 2004, Systemy Informacji Geograficznej w programach edukacyjnych uniwersyteckich studiów przyrodniczych w Polsce, ,Roczniki Geomatyki”, II, 3: 11-23.

Zwoliński Z., 2003, Geoinformacja - studia uniwersyteckie, [w:] Ogólnopolskie Sympozjum Geoinformacji „, Geoinformacja zintegrowanym narzędziem badań przestrzennych”, Wrocław-Polanica Zdrój, 15-17 września 2003, Streszczenia: 77.

Zwoliński Z. (red.), 2009, GIS - platforma integracyjna geografii, Bogucki Wydawnictwo Naukowe, Poznań.

Zwoliński Z., 2010, O homologiczności polskiej terminologii geoinformacyjnej, [w:] Zwoliński Z. (red.), GIS - woda w środowisku, Bogucki Wydawnictwo Naukowe, Poznań: 21-30.

Zwoliński Z., 2012, Geoinformacja, [w:] Dzieje nauk geograficznych i geologicznych na Uniwersytecie w Poznaniu, tom I: Historia, Praca zbiorowa, Wydawnictwo Poznańskiego Towarzystwa Przyjaciół Nauk, Poznań.

\title{
Akty prawne
}

Ustawa z dnia 18 marca 2011 roku o zmianie ustawy - Prawo o szkolnictwie wyższym (Dz.U., 2011, nr 84, poz. 455).

\section{EDUCATION IN GEOINFORMATION AND GEOINFORMATICS AT SELECTED UNIVERSITIES IN POLAND}

\begin{abstract}
The aim of the paper is to present the most important advantages of educational offers of Polish universities in the field of geoinformation or geoinformatics. Particular attention was paid to the similarities and specific characteristics at particular universities. Studies in geoinformation and geoinformatics have been conducted at seven Universities in Poland. The studies are run in the Bolognese system with bachelor's, engineering and master's degree. The number of teaching hours is varied and ranges from 1,890 to 2,524 hours for first-cycle studies and from 772 to 1,095 hours for second-cycle studies. Studies in the fields of geoinformation and geoinformatics are assessed as difficult, because they require a good mastery of issues that have been (and still are) the subject of several different types of studies: natural, geographic, geodetic, mathematical, statistical or IT. The objectives of studies can be generalized as follows: (1) knowledge necessary to understand the functioning of the geographical environment, (2) the ability to collect, process, analyze, interpret and visualize geodata using (3) modern computer techniques
\end{abstract}


and methods and/or (4) creating IT tools that support these processes. The realized fields of study are not the same. Each university describes its graduate education goals in a slightly different way: some want them to have the knowledge and skills needed to measure space and phenomena, others - to get the data well processed using IT methods, and another - to use geoinformation and geoinformatics to learn about the mechanisms of functioning environment and society.

Keywords: geoinformation, geoinformatics, GIS, education, university studies.

Dr hab. inż. Krzysztof Będkowski, prof. UŁ Zakład Geoinformacji Instytut Geografii Miast i Turyzmu Wydział Nauk Geograficznych Uniwersytet Łódzki e-mail: krzysztof.bedkowski@geo.uni.lodz.pl

Dr Łukasz Chabudziński Pracownia Geoinformacji

Wydział Nauk o Ziemi i Gospodarki Przestrzennej Uniwersytet Marii Curie-Skłodowskiej w Lublinie e-mail: lchabudzinski@poczta.umcs.lublin.pl

Dr hab. inż. Dariusz Gotlib, prof. PW Zakład Kartografii Wydział Geodezji i Kartografii Politechnika Warszawska e-mail: dariusz.gotlib@pw.edu.pl

Dr hab. inż. Witold Kazimierski, prof. AM Instytut Geoinformatyki Wydział Nawigacyjny Akademia Morska w Szczecinie e-mail: w.kazimierski@am.szczecin.pl

Dr hab. Mieczysław Kunz Katedra Geomatyki i Kartografii Wydział Nauk o Ziemi Uniwersytet Mikołaja Kopernika w Toruniu e-mail: met@umk.pl

Prof. dr hab. Zbigniew Zwoliński Instytut Geoekologii i Geoinformacji Wydział Nauk Geograficznych i Geologicznych Uniwersytet im. Adama Mickiewicza w Poznaniu e-mail: ZbZw@amu.edu.pl 